Іванова T. B.

канд. економ. наук

Національний технічний університет України «КПI»

\title{
ОСОБЛИВОСТІ ПРОГНОЗУВАННЯ МАКРОЕКОНОМІЧНИХ ПОКАЗНИКІВ КРАЇНИ З ПОЗИЦЙ ЗАБЕЗПЕЧЕННЯ СТАЛОГО РОЗВИТКУ
}

\section{ОСОБЕННОСТИ ПРОГНОЗИРОВАНИЯ МАКРОЭКОНОМИЧЕСКИХ ПОКАЗАТЕЛЕЙ СТРАНЫ С ПОЗИЦИЙ ОБЕСПЕЧЕНИЯ УСТОЙЧИВОГО РАЗВИТИЯ}

\section{FEATURES OF FORECASTING FOR MACROECONOMIC INDICATORS BY COUNTRY FROM POSITIONS PROVIDING SUSTAINABLE DEVELOPMENT}

У статті проведено аналіз теоретико-методичних аспектів прогнозування макроекономічних показників Украӥни. Досліджено прачі вітчизняних та зарубіжних науковиів з визначеної проблематики, зокрема наведено їх підходи до виділення певних етапів економічного прогнозування. Визначено основні завдання прогнозування у сучасних умовах функиіонування. Звернено увагу на специффіку розроблення методологіі прогнозування. У роботі виділено основні принципи, функиії та методи економічного прогнозування. Запропоновано здійснювати прогнозування макроекономічних показників шляхом наступних послідовних етапів: початковий, аналітичний, організачійний, прогнозний, завершальний. За результатами проведеного дослідження, представлено структурно-логічну схему методології прогнозування макроекономічних показників. Вищезазначене дозволить сформувати єдиний інструментарї прогнозування, використання якого усіма органами державного управління призведе до визначення та дотримання скоординованої економічної політики держави.

Ключові слова: макроекономічні показники, методи, принципи, етапи прогнозування.

В статье проведен анализ теоретико-методических аспектов прогнозирования макроэкономических показателей Украины. Исследованы труды отечественных и зарубежных ученых по определенной проблематике, в частности приведены их подходы к выделению этапов экономического прогнозирования. Определены основные задания прогнозирования в современных условиях функционирования. Обращчено внимание на специфику разработки методологии прогнозирования. В работе выделены основные принцииь, функиии и методы экономического прогнозирования. Предложено осуществлять прогнозирование макроэкономических показателей путем следуюших последовательных этапов: начальный, аналитический, организационный, прогнозный, завериающий. По результатам проведенного исследования, представлена структурно-логическая схема методологии прогнозирования макроэкономических показателей. Вышеупомянутое позволит сформировать единственныии инструментарии прогнозирования, использование которого всеми органами государственного управления приведет к определению и соблюдению скоординированной экономической политики государства. 
Ключевые слова: макроэкономические показатели, методы, принципы, этапы прогнозирования.

The analysis of methodical aspects of forecasting of macroeconomic indicators of Ukraine in article is carried out. Works of domestic and foreign scientists on a certain perspective are investigated, in particular their approaches to allocation of stages of economic forecasting are given. The main tasks of forecasting in modern operating conditions are defined. The attention to specifics of development of methodology of forecasting is paid. In work the basic principles, functions and methods of economic forecasting are allocated. It is offered to carry out forecasting of macroeconomic indicators by the following consecutive stages: initial, analytical, organizational, expected, finishing. By results of the conducted research, the structural scheme of methodology forecasting by macroeconomic indicators is submitted. It will allow to create one tools of forecasting, which use by all state bodies will lead to definition and observance of the coordinated economic policy of the state.

Key words: macroeconomic indicators, methods, principles, prediction forecasting.

Вступ. Однісю 3 умов забезпечення сталого розвитку країни $\epsilon$ впровадження дієвих механізмів державного управління, що дозволять успішно функціонувати економіці в умовах глобалізації. Проте, мінливість та динамічність зовнішнього середовища потребує розроблення методології економічного прогнозування, що сприятиме прийняттю обгрунтованих рішень.

Питання щодо значення, сутності, принципів, функцій та методів прогнозування розглянуто у роботах закордонних та вітчизняних науковців, серед яких: О. Ю. Бобровська [1], Т. С. Вакарчук [2], К. Б. Корєєва і О. П. Ростова [3], М. І. Линдіна [4], О. О. Фурсін [5], Л. М. Чайнікова [6] та інші. Однак, на підставі проведеного аналізу, виявлено, що недостатньо уваги приділено методології прогнозування, зокрема макроекономічних показників, що ставить дану проблему в розряд актуальних.

Постановка завдання. Основними цілями даного дослідження $\epsilon$ систематизація та обгрунтування складових елементів методології прогнозування макроекономічних показників.

Методологія. Теоретичною базою дослідження виступають досягнення зарубіжних та вітчизняних науковців. Для досягнення поставленої мети було використано наступні методи дослідження: системний підхід, метод аналізу та синтезу, структурно-логічний аналіз, прийоми логічного узагальнення.

Результати дослідження. 3 метою розроблення моделі, що дозволить спрогнозувати рівень макроекономічних показників вітчизняної економіки варто вирішити наступні завдання: 1) аналіз наявних закономірностей та тенденцій;2) визначення напрямів розвитку; 3) вибір інструментів та способів досягнення поставлених цілей; 4) розроблення певної економіко-математичної моделі. 
Однак, для розроблення методології прогнозування слід враховувати певну специфіку, а саме: 1) багатовекторність розвитку об'єкту прогнозування;

2) протиріччя макроекономічних показників; 3) відсутність певної кількості показників, що характеризують суб'єкт; 4) наявність певних факторів, що впливають на запланований та фактичний розвиток об'єкту прогнозування.

Для вирішення окреслених завдань та 3 метою врахування певної специфіки прогнозування, необхідно проаналізувати основні принципи, методи, функції, етапи, для побудови певної макроекономічної моделі.

Взагалі, економічне прогнозування грунтується на таких основних принципах [1;3]:

1) Варіативності. Пов'язано із тим, що наявними є декілька сценаріїв розвитку (по різним траєкторіям) при прогнозуванні розвитку національної економіки.

2) Системності. Даний принцип означає, що об'єкт розглядається 3 одного боку як єдина система, а 3 іншого, як сукупність взаємодіючих та відносно самостійних об'єктів для прогнозування.

3) Обгрунтованості. Передбачає поєднання економічних законів, наукового інструментарію та досвіду для побудови прогнозу.

4) Адекватності. Заснований на обліку можливих варіантів розвитку об’єкту та оцінку ймовірності реалізації прогнозу.

5) Адаптивності. Означає, що під впливом певних факторів економічні процеси змінюються, шляхом пристосування до умов.

Функціями прогнозування макроекономічних показників є [3; 5]:

1) науковий аналіз;

2) дослідження взаємозв'язків явищ у розвитку об'єкта прогнозування в конкретних умовах у певному періоді;

3) оцінка об'єкту прогнозу;

4) виявлення альтернативних варіантів розвитку;

5) накопичення певного досвіду для прийняття рішень.

Методами економічного прогнозування вважають [3; 4; 6]: 1) інтуїтивні (індивідуальні та колективні експертні оцінки); 2) формалізовані (екстраполяції: методи найменших квадратів, експоненціального згладжування, адаптивного згладжування, ковзаючих середніх; моделювання: структурне, сітьове, матричне, імітаційне).

У наукових роботах різних авторів представлено чимало поглядів на кількість та послідовність етапів здійснення економічного прогнозування, проте на даний момент відсутня єдина точка зору.

Так, О. Ю. Бобровська [1] пропонує наступні етапи процесу прогнозування: формування концепції прогнозу та інформаційної бази його 
здійснення (формулювання загальної мети прогнозу і конкретизація окремих цілей; уточнення виду, призначення результатів прогнозування i форм наведення результатів; визначення показників і характеристик стану явища, за яким складається прогноз, уточнення одиниць їх вимірювання та методів розрахунків; визначення джерел, періоду формування, збір і систематизація інформації; встановлення умов і обмежень під час формування масивів інформації; виконання дій щодо збору інформації, іiі систематизація; побудова рядів динаміки; аналіз стану, тенденцій i характеру змін параметрів прогнозованих явищ та процесів; подання результатів в аналітичній i графічній формах); здійснення прогнозу й обгрунтування його достовірності (оцінка якості i достовірності визначених показників для здійснених прогнозів; визначення сценаріїв очікуваних тенденцій змін явища, яке аналізується; розрахунки показників, що прогнозуються, за всіма обраними сценаріями і моделями прогнозування; верифікація прогнозів; наведення результатів прогнозу; оформлення результатів прогнозу і пропозиції щодо їх використання у відповідних сферах діяльності).

Автори [3, с. 35] виділяють такі етапи: передсценарний (опис об'єкту прогнозування, аналіз основних елементів, побудова системи моделей прогнозування) та сценарний.

На думку О. О. Фурсіна [4, с. 99] процедура розроблення прогнозу передбачає основні етапи: обгрунтування прогнозування; опис зовнішнього середовища; розроблення прогнозної моделі, розроблення альтернативного варіанту; оцінювання достовірності, точності та обгрунтованості розробленого прогнозу; розроблення рекомендацій щодо подальшого управління процесом; формулювання задач щодо розроблення нового варіанту прогнозу.

На нашу думку, доцільно представити процес прогнозування макроекономічних показників у вигляді таких послідовних етапів:

1) початковий (виявлення об'єктів та періоду прогнозу; формулювання цілей розроблення прогнозу; визначення джерел інформації; обгрунтування інструментів прогнозу);

2) аналітичний (формування для кожної цілі системи обгрунтованих показників; визначення групи експертів для проведення аналізу; збір та аналіз інформації для визначення стану об'єкту прогнозу);

3) організаційний (формування команди виконавців; обгрунтування системи основних показників для прогнозування);

4) прогнозний (розроблення безпосередньо прогнозу; визначення альтернативних сценаріїв прогнозу);

5) завершальний (моніторинг рівня результативності за варіантами прогнозу; розроблення системи контролю, стимулювання та регулювання процесу реалізації прогнозних значень). 
Запропонована нами структурно-логічна схема методології прогнозування макроекономічних показників представлена на рисунку.

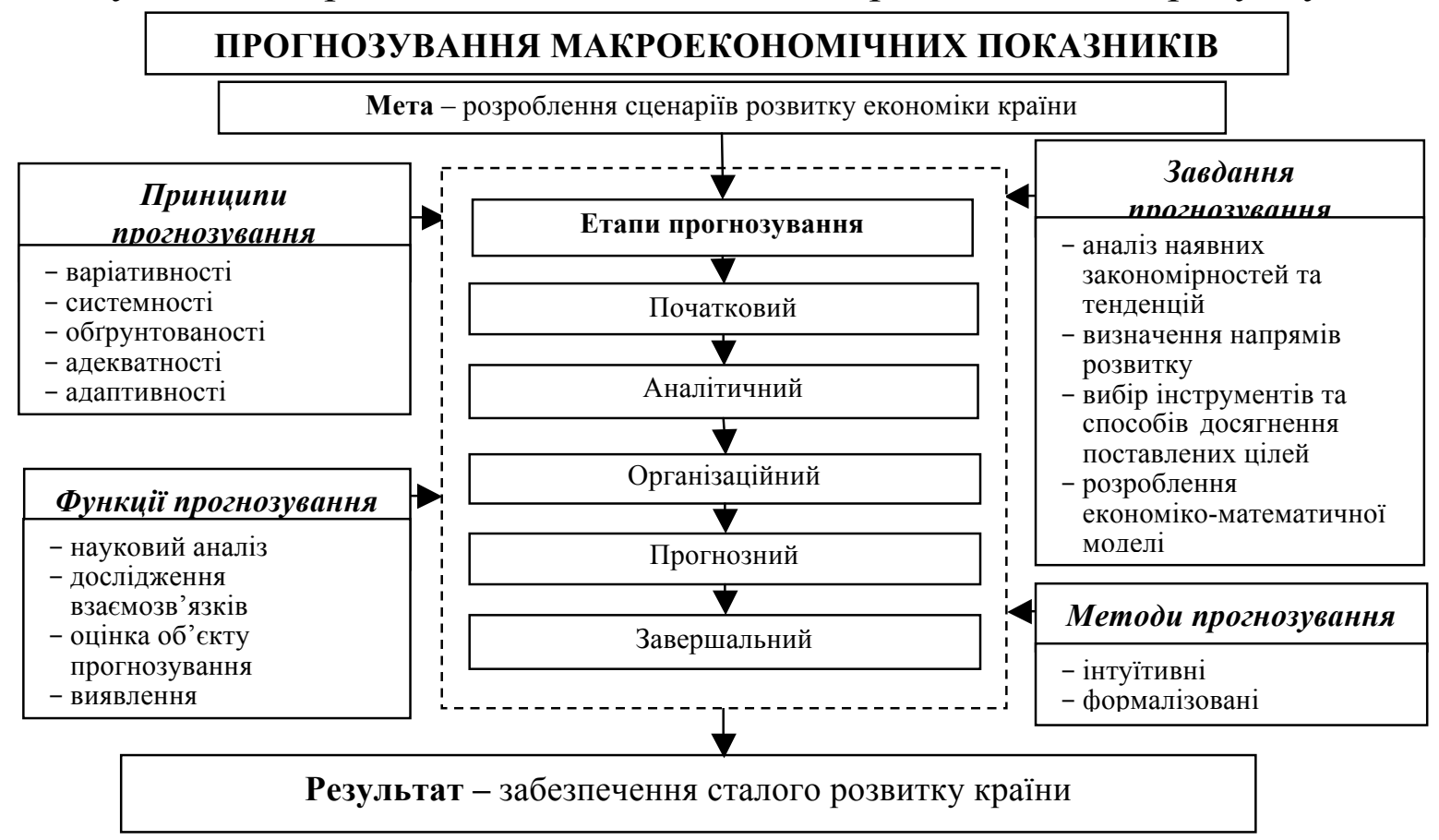

Рисунок. Складові елементи методології прогнозування макроекономічних показників країни (запропоновано автором)

Отже, невід'ємною частиною сталого розвитку національної економіки повинен стати комплексний прогно3, що дозволить сформувати єдину стратегію розвитку країни.

Висновки. Наукова новизна дослідження полягає у розробленні узагальненої структурно-логічної схеми методології прогнозування макроекономічних показників, на основі врахування основних завдань, функцій, методів та принципів.

Теоретичне та прикладне значення дослідження: удосконалення методичних підходів до прогнозування економічних показників, що сприятиме прийняттю обгрунтованих управлінських рішень та дозволить знизити вплив зовнішніх факторів на розвиток національної економіки.

Перспективою подальших наукових розробок за даним напрямом $\epsilon$ побудова економіко-математичного апарату для прогнозування розвитку економіки країни.

\section{Література:}

1. Бобровська О. Ю. Еволюція прогнозування розвитку соціально-економічних процесів: стан і напрямки удосконалення / О. Ю. Бобровська // Збірник наукових праць «Публічне адміністрування: теорія та практика». - 2011. - Вип. 2 (6). - Режим доступу до статті : http://www.dbuapa.dp.ua/zbirnik/2011-02(6)/11boysnu.pdf. 
2. Вакарчук Т. С. Державне регулювання та прогнозування розвитку національної економіки / Т. С. Вакарчук // Збірник наукових праць «Економічний Нобелівський вісник». - Дніпропетровськ : ДУЕП ім. Альфреда Нобеля, 2014. - № 1 (7). - С. 66 - 75.

3. Кореева Е. Б. Методы социально-экономического прогнозирования / Е. Б. Кореева, Е.П. Ростова. - Самара: Изд-во Самар. гос. аэрокосм. ун-та, 2011. - 60 с.

4. Лындина М. И. Методы прогнозирования для ракетно-космической промышленности / М. И. Лындина, А. И. Орлов // Научный журнал Кубанского государственного аграрного университета. - 2014. - №103 (09). - Режим доступа к статье : http://ej.kubagro.ru/2014/09/pdf/13.pdf.

4. Фурсін О. О. Методологія дослідження соціально-орієнтованого управління в контексті економічного прогнозування / О. О. Фурсін // Збірник наукових праць «Гуманітарний вісник Запорізької державної інженерної академії». - Запоріжжя: Вид-во ЗДІА, 2009. - Вип. 38. - С. $94-105$.

6. Чайникова Л. Н. Изыскание метода прогнозирования уровня стратегической конкурентоспособности региона / Л. Н. Чайникова // Журнал "Вопросы современной науки и практики. Университет им. В. И. Вернадского". - 2009. - №12 (26). - Режим доступа к статье : http://vernadsky.tstu.ru/pdf/2009/12/rus_35_2009_12.pdf. 